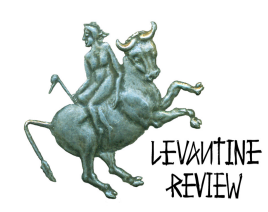

\title{
LEBANON'S NATIONAL IDENTITY: WALKING BETWEEN RAINDROPS?
}

\begin{abstract}
Hannah Stewart*
In 2006, a Byblos Bank television commercial epitomised the enduring centrality of conflict in the debate over identity in Lebanon. As the commercial unfolds, standing proudly alongside their national flags, a slew of individuals take to the stage introducing themselves as, in turn, Frenchmen, Omanis, Serbians, Americans, Colombians, Palestinians, and others, with each of their nationalities flaunted as natural a part of their being as their gender, race or name. Yet Lebanon's Cedar flag in this clip fails to invoke such intuitive national sentiments, with the "nation" (and its name) relegated to the folds of the red white and green backdrop. As Lebanon's representatives take to the stage the tone changes, jovial music is replaced by a sombre tune, and each introduction is followed by an ominous gunshot. As their flag falls crumpled to the ground, the young Lebanese introduce themselves not according to a single nationality, but in turn as Maronites, Sunnis, Shias and Druze. Then in silent contemplation, the commercial closes with a question: "when will we all become only Lebanese?"1
\end{abstract}

As a small country with a history plagued by conflict, power struggles, external interference, and the burdens of a volatile region, Lebanon seemed condemned to go on "walk[ing] between raindrops" - changing and adapting in its quest for survival, often at the cost of its own national cohesion. ${ }^{2}$ Yet, just as history has often revealed a Lebanon perennially teetering on the edge of communal violence, so did it also paint a country remarkably at peace with its diversity, advancing a splendid model of inter-communal coexistence. Lebanon's history as a refuge for persecuted minorities and an entrepôt of international trade, in some ways, fostered a unique culture of openness and tolerance making it an "oddity" in its neighbourhood, and contributing to the formation of what can be termed a "distinct Lebanese identity." A glance at Lebanon's languages, traditions, history, and culture of power-sharing, suggests that despite periods of violence and inter-communal dissentions, patterns of coexistence among Lebanon's various groups have developed organically, and often logically, since the French Mandate period in the early twentieth century.

\footnotetext{
${ }^{1}$ Byblos Bank Christmas commercial 2006, www.youtube.com/watch?v=KzEGTTCUSks

${ }^{2}$ Augustus R. Norton, "Hizballah of Lebanon: Extremist Ideals vs Mundane Politics", Council on Foreign Relations, (New York, 1999), 21.
} 
Theories of nationalism offer conflicting guidance in the search for understanding a case such as Lebanon's. Theories such as Jacobinism, regard political and cultural unity as pre-requisites for national cohesion, while Theodor Hanf emphasises the possibility of nation building based upon respect for communal differences. ${ }^{3} \mathrm{~A}$ question then begs being asked; does Lebanon's history of constitutional crises, many of which share similar traits, mean that the Lebanese are condemned to permanently battle over the nature of their national identity? Or have the painful toils of civil war, internal rivalries, and external interference, contributed to the birth of a stronger national identity and a more unified vision of Lebanon?

One must keep in mind that Lebanon's diversity in and of itself is not a unique phenomenon in the modern world of "nation-states." And so, one must ask why have nationalism and the politics of identity played such a central, often divisive, role in Lebanese society. The examination of key nodal points in Lebanon's history, from nineteenth century Mount Lebanon to the Cedar Revolution of 2005, will help shed some light on our inquiry. These nodal points have shaped and informed Lebanon's identities, at times presenting opportunities for growth and change, at other times generating crisis, conflict and insecurity.

A recent example of this juxtaposition of conflict and stability was witnessed when the UN Special Tribunal for Lebanon (STL), established after the assassination of former Prime Minister Rafiq Hariri in 2005, indicted four Hezbollah members. The indictments were met with defiance by Hassan Nasrallah, the Shia militia leader, who vowed to prevent the STL from "drag[ing] Lebanon towards strife or civil war." 4 However, a previous Nasrallah statement promising to "cut off the hand" of anyone attempting to arrest any Hezbollah member, reminded the Lebanese that the Shia militia's power to prevent civil war was matched only by its ability to polarise opinion and instigate violence and civil strife. ${ }^{5}$

Nevertheless, while the STL's actions combined with the uprising against Baathist rule in neighbouring Syria herald yet another testing and unpredictable period in Lebanon's history, Nasrallah's words-though not universally popular-appear to resonate across the country, with support for his defiant stance often transcending communal and sectarian boundaries.

\footnotetext{
${ }^{3}$ Theodor Hanf, Co-existence in Wartime Lebanon: Decline of a State and Rise of a Nation (London: I.B Tauris \& Co. Ltd, 1993), 28-29.

4 "Hezbollah Leader Nasrallah rejects Hariri indictments", $B B C$ News, www.bbc.co.uk/news/worldmiddle-east-14004096, $3^{\text {rd }}$ July 2011.

5 http://globalspin.blogs.time.com/2011/06/30/closer-to-closure-but-closer-to-crisis-lebanons-specialtribunal-names-names/, Time Online, 30 ${ }^{\text {th }}$ June 2011.
} 


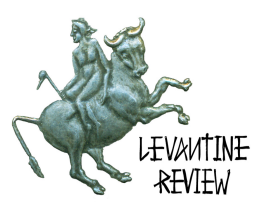

While the Byblos Bank commercial mentioned earlier implies an absence of a national identity in Lebanon, this paper suggests the opposite, demonstrating that there are as many forces of cohesion as there are division fault-lines between Lebanon's communities. Yet, unity, where it exists, has not been given scope for expression, with some actors in Lebanon going to great lengths to prevent it. Moreover, those interested in maintaining Lebanon's status quo and perpetuating communal divides have imposed the competing identities and nationalisms that have shaped Lebanese history, preventing progress and the consolidation of a cohesive national identity.

In spite of this manipulation, along with decades if not centuries of political turmoil and violent conflict, the very fact that the Lebanese state and its diverse sectarian, tribal, ethnic and family groupings have endured, attests to their commitment not only to Lebanon, but to each other as well. More powerful than competing identity and nationalism narratives, or political rhetoric and divisive conflict, is the fact that whenever faced with the spectre of partition and fragmentation Lebanon's communities have continuously reverted to a state of co-existence. This highlights the two "Lebanons" that emerge in the analysis of nationalism and identity: the state and the people.

Before considering these issues in their historical context, it is necessary to explore concepts of identity and nationalism, which both frame the arguments and introduce a relevant theoretical foundation for analysis.

\section{Nationalism and Identity: A framework}

The "birth" of nationalism is placed by scholars such as Anthony Smith around the end of the eighteenth century. ${ }^{6}$ Whilst cognisant of the plethora of factors such as religion, ethnicity and culture that pre-date the "modernist" approach, this period in history nevertheless serves as a useful starting point. Within limits, theory provides valuable benchmarks, even if it serves to simply highlight how a situation does not fit the nationalist narratives.

In the search for definitions, Smith broadly describes nationalism as an ideology upholding the nation at the centre of its concerns, with a drive to promote its wellbeing, and identifies national autonomy, unity, and identity as key to the survival of a nation. ${ }^{7}$ Yet, given the absence of national cohesion and seeming disregard for national wellbeing, we are obliged to consider whether Lebanon as a "nation" has survived, or whether it has in fact ever existed at all. Yet, perhaps it is

\footnotetext{
${ }^{6}$ Anthony D. Smith, Nationalism (Oxford: Blackwell Publishers, 2001), 5.

${ }^{7}$ Ibid., 9.
} 
not the nation but a fervent "nationalism" that has failed to materialise in Lebanon. The apparent lack of any strict defining criteria might indeed lead to the interpretation of any combination of communities or social groups as "nations," perhaps implying not a Lebanese nationalism, but nationalisms - or nations-in Lebanon. ${ }^{8}$

One of Europe's biggest exports of the twentieth century in response to the "need" for nation-building was the idea of Jacobinism, built on the premise that obstacles to political and cultural unity should be removed to allow for national cohesion. ${ }^{9}$ Conversely, Theodor Hanf identifies two ideological tendencies regarding power in multi-communal states, including "mobilisation of communal identities," and "syncretistic nationalism," which aims to build a nation based upon existing communal differences. ${ }^{10}$ Here, the need for a conscious process of nation-building is implied, but Lebanon's diversity and coexistence indicate that these concepts are neither twentieth century phenomena nor conscious creations. Indeed, Lebanon has been home to some of the oldest communities in the world, such as those of Byblos, which predate modern European "nations" and undermine the presumed modernity of nationalism. Moreover, the concept of "voluntary nationalism," involving the expression of a desire to continue a common life ${ }^{11}$ in some ways indicates that Lebanon has possessed a stronger sense of nation than many other states. Reversion to some sense of "normality" has been as characteristic as the civil strife that has torn the country apart.

For some, aspiring to a sovereign state is as important as its achievement. ${ }^{12}$ For Benedict Anderson, tangible communities or nations are in fact imagined and rely upon the manipulation of history and encouragement of nationalist sentiments to ensure a community or nation's survival. As he explains, "It is the magic of nationalism to turn chance into destiny." 13 As romantic a notion as this may be, Lebanon attests to the fact that problems arise when various groups lay claim to a country's past, present and future.

The creation of nationalism based on imagined communities, destinies and histories, does not occur by chance. For Ernest Gellner, nationalism represents the imposition

\footnotetext{
${ }^{8}$ Maurus Reinkowski, "National Identity in Lebanon Since 1990”, Orient, Vol.38, No.3, (1997), 503

${ }^{9}$ Theodor Hanf, op.cit., 28.

${ }^{10}$ Ibid., 29.

${ }^{11}$ Ernest Renan,E, cited in Homi. K Bhabha (ed.), Nation and Narration (London and New York:

Routledge, 1990), 1.

${ }^{12}$ Benedict Anderson, Imagined Communities: Reflections on the Origin and Spread of Nationalism (London: Verso, 1983), 6.

${ }^{13}$ Ibid., 11-12.
} 


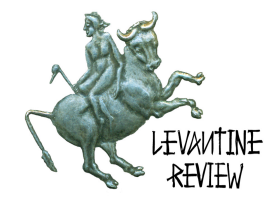

on society of an elitist "high culture"; 14 an idea furthered by Anderson who explains nationalism as a reaction by often dynastic and aristocratic powers, which fear exclusion or marginalisation in popular imagined communities. ${ }^{15} \mathrm{~A}$ nationalism constructed by elites and external actors has shaped Lebanon's national identities, from a Lebanonism harking back to a Phoenician past, to a distinctly Arab identity pushed by Baathist Syria, Nasserist Egypt, and other practitioners of Arabism in Lebanon's neighborhood.

The idea of identity itself warrants closer scrutiny. In 1943, psychologist Abraham Maslow conceptualised a Hierarchy of Needs. ${ }^{16}$ He argued that after physiological needs such as food and shelter are met, there follows the need to belong-thus giving life meaning. With these foundations in place, a secure identity can develop. ${ }^{17}$ The absence of a secure identity, often experienced by the individual as a threat to survival, contributes to distress or even personality breakdown. ${ }^{18}$ This is of equal relevance to group identity-including states. While it would be simplistic to attribute the "breakdown" of the Lebanese state to the lack of a secure identity, it is nonetheless a useful lens for analysis. The existence of secure religious identities ensured that Lebanon's respective confessional groups remained unshaken, while the absence of a secure national identity achieved the opposite for national cohesion.

When the survival of one element of a person's identity is threatened, it becomes dominant, ${ }^{19}$ implying that identities are both changeable and multi-layered. During the Lebanese civil war of 1975-1990, it was not in the interests of opposing militias for their communities, defined predominantly by religious sect, to explore these "layers" and reach the conclusion that they were not so different after all. Yet, this is the reality, as Amin Maalouf articulates: "If we assert our differences so fiercely it is precisely because we are less and less different from one another." 20 One explanation for the drive to assert group differences relates to the need to improve group status; an impulse that is exaggerated where exit from a group is difficult or

\footnotetext{
${ }^{14}$ Ernest Gellner, Nations and Nationalism: New Perspectives on the Past (Oxford: Blackwell Publishers Ltd, 1983), 57.

${ }^{15}$ Benedict Anderson, op.cit., 110.

${ }^{16}$ Abraham Maslow, "Theory of Human Motivation", Psychological Review, Vol.50 (1943): 370-396

${ }^{17}$ Ibid.

${ }^{18}$ William Bloom, Personal Identity, National Identity and International Relations (Cambridge: Cambridge University Press, 1990).

${ }^{19}$ Amin Maalouf, In the Name of Identity: Violence and the Need to Belong (New York: Penguin Group Inc., 2003), 13.

${ }^{20}$ Ibid., 120 .
} 
impossible. ${ }^{21}$ For Lebanon, with a society centred on entrenched group identities, these concepts are significant.

Religion, for its part, is possibly just as central to the need to belong. In an unpredictable world, the stability that religion offers is attractive, and as with destiny, religion locates individuals eternally. ${ }^{22}$ Maybe then, it is not religion itself that is important to Lebanon, but the security that it provides in the absence of other sources of stability. Similarly, tribal distinctiveness, and clan and kinship ties which remain a central fact of Lebanese life, ${ }^{23}$ demonstrate that traditional identity references prevail over imposed and politically-motivated identity narratives.

Yet, no matter how sophisticated the theory, an individual's identity can never be fully articulated. ${ }^{24}$ We are left with no alternative, therefore, but to construct our own version of "others" based on observations, education, memory, and past experiences. ${ }^{25}$ This "construction" is vital to understanding Lebanon, with "unavoidable" identity construction, contrasting sharply with the conscious campaign for competing national identities driven by self-interested states and individuals. It is against this theoretical backdrop that the debate over Lebanon's national identity should be reconsidered.

\section{The Beginnings}

Difficulties in determining Lebanon's national identity are matched by the challenges of identifying a point from which to begin. Mount Lebanon provides an appropriate starting point in many ways. For those seeking refuge on Mount Lebanon, "returning," in any sense of the word, was not an option, and the roots laid by the rich mixture of peoples that made Mount Lebanon home, fostered a commitment to the land which has endured to this day. However, the second half of the 1800s, described by Winslow as decades of "convulsion" and "transformation" for Lebanon's inhabitants, ${ }^{26}$ were characterised by other unfaltering realities. Realities that are still extant today; namely, entrenched patronage, foreign

\footnotetext{
${ }^{21}$ Jeffrey Seul, "Ours is the Way of God: Religion Identity and Intergroup Conflict", Journal of Peace Research, Vol.36, No.5. (September 1999), 553-569, 557.

${ }^{22}$ Ibid., 559-560.

${ }^{23}$ William Harris, The New Face of Lebanon: History's Revenge (Princeton: Markus Wiener Publishers, 2006), 93.

${ }^{24}$ John.E Joseph, Language and identity: National, Ethnic, Religious (Basingstoke \& New York: Palgrave Macmillan, 2004), 1.

${ }^{25}$ Ibid., 8 .

${ }^{26}$ Charles Winslow, Lebanon: War and Politics in a Fragmented Society (London \& New York, Routledge, 1996), 28.
} 


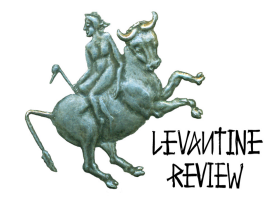

interference, and conflicts between elites. ${ }^{27}$ It is in 1860, when these realities collided, culminating in a short but brutal civil war, that the first "nodal point" can be identified. The trigger for the battles of 1860 appears trivial; in August 1859, near the village of Beit Miri, two pack animals collided, one driven by a Maronite and the other by a Druze. An armed confrontation developed between the two drivers leading to a sectarian battle, which escalated in the spring of $1860 .^{28}$

To understand how such feuds could develop between communities that had for years avoided confrontation, attentions must be focused on the personal interests at play, which in many ways set the tone of Lebanon's political history to date. What began as peasant uprisings against landowning sheikhs from their own faiths, were transformed by those same sheikhs into violent confrontations between peasants from different religious communities. However, manipulative elites were not solely responsible for these developments-with the Ottomans, religious leaders and European powers contributing to the tensions. As the Druze rampaged on Mount Lebanon razing Christian villages to the ground, Britain and France who sought power in the region, and who were threatened by the prospect of Muslim domination over Mount Lebanon's Christian population, showed little urgency in resolving the disturbances. Ultimately, however, it was with French involvement and a crackdown by the Ottomans that violence was brought to an end. ${ }^{29}$

What followed provided the foundation of a political system tinged with confessionalism - a method of fostering co-existence between diverse religious and ethnic groups, with power afforded to each group according to its size and influence in the region. This, however, opened the doors to increased foreign interference in Lebanon. Out of the civil war of 1860 came the Règlement Organique. This regime altered Lebanon both politically and geographically, limiting it to the mountain. It also created a new jurisdiction led by a non-Lebanese Christian accountable to the Ottomans, and provided for the establishment of a council, which introduced representation on a communal basis. Though the Règlement Organique undermined feudal affiliations and reduced elite power, the positions of leading families were secured through the absorption of clientalism into the political system. ${ }^{30}$

While the ability to coexist had been evident for a long time between Mount Lebanon's diverse groups, events leading up to 1860 and the resulting civil strife are

\footnotetext{
${ }^{27}$ Ibid., 35.

${ }^{28}$ Kamal Salibi, The Modern History of Lebanon (Worcester \& London: Weidenfeld \& Nicolson, The Trinity Press, 1965), 83.

${ }^{29}$ Ibid.

${ }^{30}$ A. Nizar Hamzeh, "Clientalism, Lebanon: Roots and Trends", Middle Eastern Studies, Vol.37, No.3., (July 2001), 167-178, 170.
} 
instructive on a number of levels, especially as pertains to identity and nationalism. In the nineteenth century, ingredients were already in place for the formation of identities along a number of lines. Identification according to family and tribe had long been dominant, with political and social privileges determined by family affiliation, class, and social status. It would of course be misleading to disregard religion as an important identity referent in the preceding years; but it was not until the period 1858 to 1861 that religious identities became the main trigger of warfare on Mount-Lebanon. Even then, religious divides were orchestrated, largely by powerful individuals and external actors, who inflamed tensions between peasant communities.

A unifying factor that appeared to transcend communal divides was that of a certain identification with Mount Lebanon as a homeland. While Mount Lebanon's borders were subject to change, the belief in the idea of a Lebanon was perhaps of greater significance, especially among the inhabitants of Mount Lebanon proper. Struggles over ownership of the Mountain and a sense of belonging to it laid foundations for the competing nationalisms, which plagued Lebanon in the years to come. However, following 1860, "even the staunchest Christian nationalists realised that survival involved compromise." 31

At this time, without the constraints associated with an officially recognised state, the communities of Mount Lebanon had the opportunity to resist change, but chose not to do so. This choice was to be eroded over time, as pacts, responsibilities associated with statehood, and pressures, were exerted by regional and international forces. Whether due to a real desire to coexist or simply as a matter of pragmatism, the fact that the Lebanese chose to proceed with a vision of Lebanon in 1860 is a testament to the recognition that coexistence and unity were preferable. In this sense, little has changed in modern Lebanon of our times.

The last decades of the nineteenth century marked the emergence of an Arab nationalism championed initially by some of Lebanon's Christians, with a degree of collaboration between Christian Arab nationalists and Christian Lebanese nationalists, and greater Christian-Muslim cooperation. Arab Nationalism called for political union of the Arab-defined world based upon common Arab civilization, historical heritage and linguistic ties. The ideology was headed by key figures including Egypt's Gamal Abdel Nasser and the Damascene Christian Michel Aflaq, cofounder of the Arab Socialist Ba'ath Party. ${ }^{32}$ The rise of Arab nationalism coincided with the decline of the Ottoman Empire in the early twentieth century. However,

\footnotetext{
${ }^{31}$ Kamal Salibi, op.cit., 153.

${ }^{32}$ Charles Smith, "The Arab-Israeli Conflict", in Louise Fawcett, International Relations in the Middle East (New York: Oxford University Press, 2005), 220.
} 


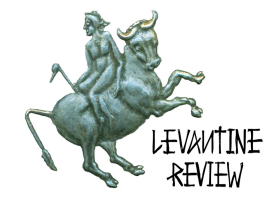

with Islam serving as a key identity referent and central feature of selfhood for many Middle Eastern Muslims, Arabism's secular ostentations proved unattractive, rendering its steady decline in subsequent decades all but inevitable. This, combined with defeat during the 1967 Six Day War which inflicted a serious blow to Nasserism and shattered the illusion of pan-Arab unity, meant that Arabism's days were numbered. Nonetheless, the relative success and region-wide popularity of Arab nationalism along with the inter-religious cooperation that it fostered for a time, indicates at least that a nationalism ascribed to by various religious groups, in the same physical and intellectual space, is not untenable.

\section{"Greater" Lebanon?}

While the Règlement Organique reduced Mount Lebanon's borders, the establishment of Greater Lebanon in 1920 reversed this process. Anticipating the fall of the Ottoman Empire, meetings between France and Britain in the spring of 1916, resulting in the Sykes-Picot Agreement, prepared the region for "restructuring," and the "birth" of Greater Lebanon paved the way for French presence in the Levant-one that would remain in place for the next twenty five years. $^{33}$

Two significant political developments followed the creation of Greater Lebanon. 1922 saw the introduction of an electoral system that allotted political office and representation according to the numerical strength of each of Greater Lebanon's communities. Then, the introduction of the 1926 Constitution served as a precursor to the National Pact of 1943 re-enforcing confessionalism, with government positions, again, allocated along confessional lines, and encouraging greater political participation and recognition of the state, particularly among Lebanon's Muslim communities.

The Lebanese, Arab, and Greater Syrian nationalisms that had developed in the late nineteenth century dominated thinking in Lebanon. ${ }^{34}$ Greater Syrian nationalism, pre-dating the modern Syrian state, advanced the notion of a "Greater Syria" based on geographic boundaries encompassing southern Turkey, Lebanon, Israel, Palestinian territories, Jordan and Iraq. Greater Syrian nationalism not only rejected Arab claims to "Greater Syria," but also dismissed the perceived or imputed Arab identity of this imagined emerging "Syrian" entity. Moreover, Greater Syrian nationalism was secular in nature; a fact that appealed to many Christians and other non-Muslim Arabophones, especially in the light of increasing Muslim assertiveness

\footnotetext{
${ }^{33}$ Meir Zamir, Lebanon's Quest: The Road to Statehood 1926-1939 (London: I.B Tauris \& Co. Ltd, 1997), 2.

${ }^{34}$ Kais Firro, Inventing Lebanon (London \& New York: I.B Tauris \& Co. Ltd, 2003), 21.
} 
and the still fresh memories of massacres on Mount Lebanon and in Damascus in the early 1860s. This rejection of Arab identity was carried forward into the twentieth century, with the Syrian Social Nationalist Party, founded by Antun Saadeh in the 1930s, championing the shared historical, social and cultural roots of Greater Syria at the expense of specifically Arab features.

Lebanonism, or Lebanese nationalism, also opposed Arab nationalism and evoked a Phoenician past with ties to the West. Being largely Christian-dominated, Lebanese nationalism judged the incorporation of larger Muslim populations into Lebanon as irreconcilable with its ideology and rejected the "Arab lens," setting the Lebanese people apart from any concept of an "Arab nation."

The creation of Greater Lebanon with its clearly demarcated geographical borders, and increasing recognition of the state encouraged by greater political representation, facilitated and shaped Lebanon's nationalisms over the coming decades. However, for the Arabophones of the Ottoman Empire, national consciousness, where it existed, was distorted by other traditional loyalties. ${ }^{35}$ This was not an experience restricted to Ottoman times, with tribal, sectarian and family ties often superseding and trumping the nation to this day.

Nevertheless, identities and allegiances are complex and multilayered. The competing loyalties amongst the Arabic-speakers of the Ottoman Empire do not, therefore, undermine the validity of Lebanon's emerging nationalisms. Rather, they attest to the fact that national consciousness and identity are blurred and shaped by other experiences and affiliations, and often necessarily so. This presented nothing new to Lebanon's communities, and it is here that the separation between state and society is evident. Though the ingredients of national consciousness had arguably long been in place at a societal level, resulting from an amalgamation of affiliations, which physically and psychologically tied groups of people to each other and to the land, the "top-down" campaign to promote nationalist narratives to suit the agendas of high politics now necessitated a far more conscious and engineered approach.

While the creation of Greater Lebanon and increased political participation engendered through the Constitution had encouraged recognition of the state, dismemberment and demarcation of territory, in the eyes of many, signified the creation of artificial entities through the exploitation of religious, sectarian, ethnic and geographic diversity. ${ }^{36}$ With hopes for an Islamic state dashed, aspirations among many Muslims turned to unification with Syria or to the creation of a wider

\footnotetext{
${ }^{35}$ Kamal Salibi, A House of Many Mansions: The History of Lebanon Reconsidered, (London \& New York: I.B Tauris \& Co. Ltd., 2005), 20.

${ }^{36}$ Meir Zamir, op.cit., 2. 


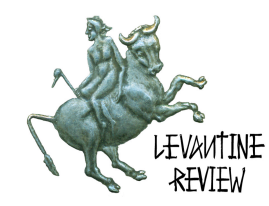

Arab state. Either way, most Muslims were unanimous in their rejection of a Lebanese identity arguably imposed by France, which stressed Lebanon's Christian roots and timeless ties to the West. ${ }^{37}$ Despite some progress regarding political participation, the legitimacy of the Lebanese state and its "associated identities" were a source of tension from the outset. Christian support for the creation of a larger state was also far from unanimous, with the incorporation of a wider mix of communities-predominantly Muslim-into the "Christian homeland" deemed an unattractive prospect.

Aided by Lebanon's elites and foreign powers, Lebanon's nationalisms were adopting religious overtones, with Arabism becoming increasingly associated with Islam, and the emergent Lebanese nationalism and Greater Syrian nationalism being predominantly Christian in their leanings. Yet, disagreements within religious groupings were as rife as those between them, with some Druze and Shia supporting Greater Lebanon, and with some Christians imbued with Arab nationalist sympathies opposing the idea of a distinct Lebanese entity. For many of Lebanon's Christians the creation of Greater Lebanon and thus a broader mix of communities-especially increased Muslim populations-threatened their dominance and the security of their Christian "homeland"; while for Lebanon's Muslim and Druze minorities, Greater Lebanon could pave the way for increased and fairer representation of their respective communities. Furthermore, divisions between religious groups were compounded by ideological divisions within the Christian camp, and by Muslim rifts-especially concerning Sunni dominance in a nascent state with an assertive Christian element. ${ }^{38}$

In this context a paradox emerges. Though relatively new, both Lebanonism and Arabism laid claims to a history so ancient, their legitimacy could hardly be put into doubt. ${ }^{39}$ This mixture of old and new suggests progress regarding national consciousness on the one hand, but an inability to let go of a glorified past on the other. Either way, in the 1920s Lebanon's divergent nationalisms ended up dividing the nascent state rather than consolidating it.

In some ways, the creation of Greater Lebanon did signify a point of no return. Yet European involvement in Lebanon saw the comparative freedom of choice once available slowly shrinking. An "official Lebanon" had been established with extended borders, ${ }^{40}$ but in the process, autonomy was lost. Decisions in the decades to come were to be determined by foreign forces, physically present, but

\footnotetext{
${ }^{37}$ Theodor Hanf, op.cit., 66.

${ }^{38}$ Theodor Hanf, op.cit., 70.

${ }^{39}$ Kais Firro, op.cit., 30.

${ }^{40}$ Kamal Salibi, The Modern History of Lebanon, op.cit., 167.
} 
emotionally removed from Lebanon. Hanf claims that "a nationalism built on

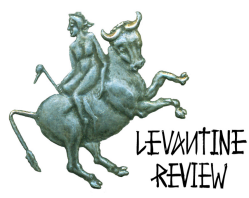
internal coexistence was the Lebanese form of collective self-love." 41 Perhaps only those who did not genuinely share this "love" for Lebanon were prepared to act to the detriment of the state.

The 1926 Constitution imposed no binding principles for inter-communal cooperation, in a way encouraging a syncretistic form of nationalism. Yet a cohesive, democratic government remained elusive. ${ }^{42}$ Ironically, the Constitution required that the president swear loyalty to the "Lebanese nation"; 43 a concept that remains as unclear today as it had been back in 1926.

A unifying nationalism may have been absent, but continued cooperation between communities illustrates the enduring desire for Lebanon's survival. Here, we are reminded of Anderson's and Gellner's view of nations and nationalism as constructs of the bourgeoisie and intelligentsia. ${ }^{44}$ Competitions over nationalism and identity arose amongst Lebanon's elites at the state level, but were not necessarily reflected in society at large. It is accepted that nations and nationalism can exist without a state ${ }^{45}$ but with nationalism residing predominantly with Lebanon's elites it may equally be worth considering that nationalism can exist with a state and without a "nation."

\section{A Gentleman's Agreement}

If the Règlement Organique and the 1926 Constitution upheld a sectarian basis for representation in Lebanon, the National Pact of 1943 consolidated it. An unwritten "gentleman's agreement" originally designed as a temporary measure to achieve independence and settle competing Muslim and Christian aspirations, the National Pact, in fact, "unintentionally formed the bedrock of Lebanese political life for the rest of the twentieth century." 46

Rather than signifying a departure from the past, however, the National Pact served to preserve the positions of religious and traditional leaders ${ }^{47}$ to such a degree that, as Hanf explains, clientalism "made a mockery of the electoral process and the

\footnotetext{
${ }^{41}$ Theodor Hanf, op.cit, 71.

${ }^{42}$ Michael Kerr, Imposing Power-sharing: Conflict and Coexistence in Northern Ireland and Lebanon (Dublin: Irish Academic Press, 2005), 26.

${ }^{43}$ Kamal Salibi, The Modern History of Lebanon, op.cit., 167.

${ }^{44}$ Benedict Anderson, op.cit., 110, \& Ernest Gellner, op.cit., 57.

${ }^{45}$ See for example, Anthony D. Smith, Nationalism, op.cit., 12.

${ }^{46}$ Michael Kerr, op.cit., 112.

${ }^{47}$ Itamar Rabinovich, The War for Lebanon 1970-1985 (Ithaca and London: Cornell University Press, 1985), 24.
}

ISSN: 2164-6678 
functions of legislature." 48 But the National Pact was important for what it represented 49 - compromise on all sides - though many saw it as a gesture, rather than a serious commitment to change. ${ }^{50}$ This was to characterise Lebanese politics in the years that followed.

Despite these "compromises," the achievement of independence was engineered predominantly by foreign powers with Lebanese elite compliance. "Independent Lebanon" was not created through social mobilisation or collective struggle-a reality that profoundly affected the formation of nationalism and identity in the young state. ${ }^{51}$ Just as class-based struggles of the nineteenth century were transformed into religion-infused clashes, Lebanon under the Mandate was "transformed" into a state with an Arab guise. ${ }^{52}$

However, disenchantment with the French reinforced Lebanon's imputed Arab image, with a Christian-Muslim alliance against the French producing the "Arab face" formula, which saw Lebanon's previously divergent communities uniting around a perceived Arabness, and against French interference. ${ }^{53}$ Here parallels can be drawn with many of Lebanon's 'nodal points' in terms of the pragmatic approach to political alliances displayed by Lebanese elites; alliances which invariably did not last. Indeed, Winslow aptly refers to the convergence of interests in 1943 as a "moment of solidarity."54

As with Lebanon's "Arab face," consociational ${ }^{55}$ government was not an entirely "imposed" notion. Between 1943 and 1975 Lebanon's 'secular' parties did not appeal to the electorate, ${ }^{56}$ with the Christian Kata'ib, the Druze-dominated

\footnotetext{
${ }^{48}$ Theodor Hanf, op.cit., 80.

${ }^{49}$ The National Pact established that the President was always to be Maronite, the Prime Minister: Sunni, the President of the National Assembly: Shi'a and the speaker of Parliament: Greek Orthodox. Parliament members were to be admitted according to a ratio of six to five favouring the Christians. Leonard Binder, Politics in Lebanon (New York: John Wiley \& Sons, Inc, 1966).

${ }^{50}$ Charles Winslow, op.cit., 80.

${ }^{51}$ Ussama Makdisi, "Reconstructing the Nation-State: The Modernity of Sectarianism in Lebanon", Middle East Report, No. 200 (July-September 1996), 23-30, 24.

${ }^{52}$ Raghid El-Solh, Lebanon and Arabism: National Identity and State Formation, (London \& New York: I.B Tauris \& Co. Ltd, 2004), 287.

${ }^{53}$ Ibid., 288.

${ }^{54}$ Charles Winslow, op.cit., 75.

55 Consociationalism is a concept developed primarily by Arend Lijphart. Broadly, it refers to a form of power-sharing which guarantees group representation and is often suggested for managing conflict in deeply divided societies. For more information see Arend Lijphart, Democracy in Plural Societies: A Comparative Exploration (New Haven: Yale University Press, 1977), and the work of Brendan O'Leary, John McGarry and Michael Kerr.

${ }^{56}$ Theodor Hanf, op.cit.
} 
Progressive Socialist Party, and the Sunni Najjade providing greater representation in the eyes of their respective communities. ${ }^{57}$ This preference indicates government failings as much as a desire for religious representation, and further illustrates the gulf between the political elites and wider society.

Crucially, although a strong "national" identity remained absent following the National Pact, the desire for an independent state and co-existence within it survived. However, achieving independence is one thing, but knowing what to do with it is entirely another. As Winslow suggests, "[in] the wonderful acts of winning independence... it was easier to oppose the French than to establish Lebanon." 58

Lebanon's Sunni leadership came to accept the concept of an independent Lebanese state that would be acceptable to the Maronites, on the proviso that the French Mandate would be abolished as a result. In the wake of increasing alienation from the French, large numbers of the Christian socio-economic elite in Beirut now endorsed a confessional power-sharing arrangement within the parameters of an independent Lebanese state. Furthermore, persistent French presence led to a degree of conciliation and cooperation between those pushing for Arab unity, and the Lebanese nationalists. Arab nationalist leaders such as Riad Solh and fellow Arab unionists acknowledged the need to moderate their approach in order to gain the support of Lebanon's Christians, in an effort to end French control. Meanwhile, many Maronite leaders also acknowledged the need to accommodate Arab nationalism to some degree, in the pursuit of self-governance and to rid Lebanon of colonial rule. 59

A fundamental problem, however, lay in the interpretation of the so-called National Pact, with Sunnis regarding the Muslim-Christian agreement as a necessary but temporary step in achieving Arab unity, and many Christians regarding the agreement as a permanent solution for Lebanon. In the years to follow, Lebanon's National Pact bore little resemblance to the agreement that was brokered in 1943, and was in many ways a myth, with no significant new power-sharing agreement emerging between Lebanon's communities. ${ }^{60}$

As patterns emerge between the Règlement Organique, the Constitution of 1926, and the National Pact, it is tempting to conclude that a "point of no return" remained out of reach. Indeed, although steps were taken towards power-sharing, the National Pact in some ways provided far less flexibility and accommodation than the 1926

\footnotetext{
${ }^{57}$ Charles Winslow, op.cit., 75.

58 Ibid., 78.

${ }^{59}$ Micahel Kerr, op.cit, 124.

${ }^{60}$ Ibid., $122 \& 123$.
}

ISSN: 2164-6678 


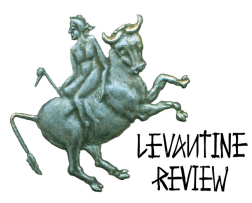

Constitution. ${ }^{61}$ Hanf stresses however, that the problem of rigidity lay not in the National Pact itself, but in its interpretation. ${ }^{62}$ With the persistence of the centrality of the Zu'ama inside Lebanon - the elite power base founded on tribal and sectarian affiliations-traditional allegiances prevailed and the potential that the National Pact held for change was not realised.

In 1860 identities had been comparatively "fluid," but the National Pact created a situation in which being Lebanese implied definition based on religious affiliation. ${ }^{63}$ However, the development of religious identification lay not in increased religious representation itself, but in the distribution of power and, once more, in the interpretation of the National Pact. While a political system alone may not be capable of creating identity, it can create grievances between neighbours, where none might have existed before.

In 1943, the differences between Lebanonism and Arabism were set aside in favour of independence. These two nationalisms persisted, but they were now defined by way of "religious" nomenclatures, with Lebanese nationalism regarded as conterminous with Christianity, and Arabism synonymous with Islam. Both in terms of identity and the political system, it seems that developments in 1943 amounted to little more than futile attempts to re-invent the wheel. While ruling elites and external powers may have often blocked expressions of a cohesive Lebanese identity, in 1943 they provided a focus which united Lebanon's different communities-but this focus was not fated to last. According to Harris, "[the] problem among Maronites, Shi'a and Druze has been that although all have had an interest in Lebanon, it has not been the same interest in the same Lebanon."64

\section{8: Internal and External Tensions Collide}

The external actors and changing international environments that had long affected Lebanon were to become all the more potent in the 1950s. This time, external interest was not restricted to competition between European powers. Pan-Arabism was now on the rise, and new power-struggles were surfacing within the Cold War context. Yet, external factors alone cannot explain the rapid evolution of conflict in 1958 into an internal sectarian insurrection. The rise of pan-Arab nationalism and the creation of the United Arab Republic between Egypt and Syria undoubtedly contributed to Christian-Muslim tensions over the nature of the Lebanese state. The

\footnotetext{
${ }^{61}$ Theodor Hanf, op.cit., 73.

${ }^{62}$ Ibid.

${ }^{63}$ John C. Rolland, Lebanon: current Issues and Background (New York: Nova Science Publishers Inc, 2003), 69.

${ }^{64}$ William Harris, op.cit., 80.
} 
1958 civil war, which collided along the fault-lines of these internal and external tension points, illustrated the fragility of the state of Lebanon, whilst demonstrating again, the resilience of impermeable traditions and allegiances. The compromise that ended the conflict had significant consequences in the years to follow. ${ }^{65}$

Meanwhile, within the Lebanese government, affiliations were loose and changeable, and focus centred on high-level politics, which led to political alienation and hindered allegiance to the state. ${ }^{66}$ In fact, attachment to the state in 1958 was arguably weaker than it had been in 1943. Furthermore, attempts by President Camille Chamoun at modernisation and reform challenged Lebanon's traditional systems, proving unpopular amongst some sectors of society. ${ }^{67}$ This demonstrated that in a society anchored by hard and fast traditions, change is often unwelcome.

The killing of a prominent Maronite journalist on $8^{\text {th }}$ May 1958 prompted a general strike and violent (largely sectarian) clashes across Lebanon. Ensuing American "assistance" brought with it a degree of containment and control. But provocative statements made by then Prime Minister Rashid Karami, and the disappearance of a prominent journalist affiliated with the Christian Kata'ib Party, instigated angry reactions from some of Lebanon's Christian communities. Subsequently, a general strike and violent reprisals paralysed Lebanon and exacerbated sectarian divides. ${ }^{68}$

The crisis of 1958 ceased with a recognition that the government could not succeed without representation of the (Christian) Kata'ib and pro-Chamoun groups. What's more, the acceptance of broader representation signified a shared interest in Lebanon's survival as a state. ${ }^{69}$ The Shihab presidency, which followed Chamoun's administration, marked a new era in Lebanese politics. But, whilst helping Lebanon out of crisis, the fundamental question over the exact nature of Lebanon, several years on from the National Pact, remained unanswered, with Lebanon settling instead for cosmetic reform. ${ }^{70}$

Nevertheless, Shihab's reforms and Lebanon's economic success at that time impacted upon nationalism, with advocates of Lebanonism capitalising on this economic success, drawing parallels with its Phoenician past to demonstrate that Lebanon represented far more than an imputed Arab entity. ${ }^{71}$ This, along with the

\footnotetext{
${ }^{65}$ Itamar Rabinovich, op.cit., 28.

${ }^{66}$ Kamal Salibi, A House of Many Mansions: The History of Lebanon Reconsidered., op.cit., 189.

${ }^{67}$ Theodor Hanf, op.cit., 115.

${ }^{68}$ Kamal Salibi, The Modern History of Lebanon, op.cit., 202.

${ }^{69}$ Itamar Rabinovich, op.cit., 29.

${ }^{70}$ Ibid.

${ }^{71}$ Kamal Salibi, A House of Many Mansions: The History of Lebanon Reconsidered, op.cit., 191.
} 


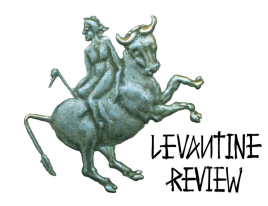

rise of Arab nationalism, polarised Lebanon's Muslims and Christians, yet again, undermining attachment to the state, but not necessarily the desire for coexistence. Indeed, during the civil war of 1958, the central identity referents remained largely tribal and familial, and, despite descent into what had been described as sectarian warfare, contact between Muslims and Christians never really ceased. ${ }^{72}$

Having survived the events of 1958, Lebanon in some respects had reached a point of no return. Power-sharing, for its part, was a compromise, but one which Lebanon's decision-makers were willing to make. However, these compromises implied benefits for external actors angling for influence, and costs for those on the inside left to endure the resulting inefficiency of power-sharing between ideologically and religiously opposed politicians. Yet, O'Leary's claim that “[at] most, consociation is a politics with a shared vision of catastrophe"73 indicates that, at least in this vision, Lebanon was united.

Although in 1958 the trust and confidence in the state-required for the formation of secure identities - was absent, these requisites were provided by the constants of tribe, clan and family. In this sense, Lebanon's inhabitants have long been aware of their identities and allegiances, reserving the struggle over Lebanon for high politics and self-interested leaders.

\section{Descent into Civil War}

By 1969, the Lebanese state was once again weak and fragile with tensions exacerbated by divided allegiances over the Palestinian issue. The signing of the Cairo Agreement in 1969, masqueraded as respecting the principles of sovereignty and security in Lebanon, achieved the total opposite. The Cairo Agreement allowed the Palestinians freedom of action from any location within Lebanon, and effectively created a "Palestinian State" within Lebanon. Although the emergence of a Palestinian nationalism and the increasing presence of Palestinian militias would not impact directly on Lebanese identities, it fundamentally questioned pre-existing Lebanese allegiances; where Arab nationalism once stood, Palestinian nationalism, and an adapted Arabism, now vied for position.

Fundamental sticking points proved insurmountable; the official recognition of Lebanon as an "independent Arab country" as called for by some, proved an inconceivable prospect to the Kata'ib (and other Christian Lebanese parties) as long as Arabism was equated with Islam. Similarly, calls for secularisation were

\footnotetext{
${ }^{72}$ Kamal Salibi, The Modern History of Lebanon, op.cit., 204.

${ }^{73}$ Brian O’Leary, in Michael Kerr, op.cit, xxii.
} 
irreconcilable with Islam for some sections of the Muslim establishment. ${ }^{74}$ However, it was perhaps Lebanon's Christians who feared the prospect of secularisation most, with this combination as threatening as the Pan-Arabism that preceded it. Under this perceived threat, "Lebanese" nationalism was sharpened and the answer to the problem became a military one, with Christian militias leading the struggle.

As the Lebanese state teetered on the verge of collapse, the causes of violence were in turn attributed to a Christian desire to protect the lifestyle of their areas, and a Palestinian desire to defend the position that they had achieved and the political environment that facilitated it. ${ }^{75}$ Yet, it would be simplistic to solely blame the Palestinians for Lebanon's woes. As usual, contentious issues were exploited by politicians, elites, and sovereign states who recognised the value in manipulating identities and fuelling fires that could have been extinguished much earlier had there been the will to do so.

The precedent of fighting between Palestinian and Christian Kata'ib militia-the former supported by many Lebanese Arabists, and the latter by the Lebanese Army-meant that the conflict could be transformed into an intra-Lebanese struggle at any moment. ${ }^{76}$ Government "attempts" to control the Palestinian militias tested people's loyalty to the state, with the attraction of independence on one hand, and the pull of Arabism on the other.

Despite this, by the mid-70s, Lebanon had achieved its lowest level of political mobilisation along sectarian lines since independence, and communities were increasingly adopting conciliatory stances towards "opposing" identities. ${ }^{77}$ However, this situation was not fated to last. In early 1975, the Lebanese were forced to take sides once more. A sequence of events unfolded, catapulting Lebanon into a fifteen-year civil war. From the bloody end to a fishermen's protest in February, to the killing of Christians at the consecration of a church in Beirut and Christian Kata'ib (Phalange) bombing of a bus occupied mainly by Palestinians in retaliation, it was not long before Lebanon would descend into chaos. ${ }^{78}$ With the Cairo Agreement and Lebanon's spiral towards civil war, keen bystanders, including Israel and Syria, waited for opportunities to capitalise on the situation. Any

\footnotetext{
${ }^{74}$ Theodor Hanf, op.cit., 209.

${ }^{75}$ Itamar Rabinovich,I., op.cit., 44.

${ }^{76}$ Theodor Hanf, op.cit., 169.

${ }^{77}$ Farid El-Khazen, The Breakdown of the State in Lebanon 1967-1975 (Massachusetts: Harvard University Press, 2000), 238.

${ }^{78}$ Brenda Seaver, "The Regional Source of Power-Sharing Failure: The Case of Lebanon", Political Science Quarterly, Vol.115, No.2, (2000), 247-271, 256.
} 


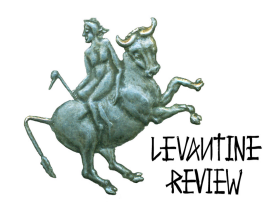

modicum of autonomy that Lebanon may have enjoyed prior to 1969 was now disintegrating.

Regardless of increasing "internationalisation" of Lebanese affairs, age-old squabbles were still playing out between Lebanon's elites, with fear of losing power outweighing the fear of the destruction of the state. In 1975, just as in 1860 and 1958, while the ruling elites fought amongst themselves, the Lebanese were either drawn into conflicts not of their own making, or else subjected to their consequences.

So it was, events of 1969 and 1975 did witness a shift in Lebanese identities, but in a manner detrimental to national cohesion, pitting religious communities against each other and encouraging identities based on differences from "the other." Charles Winslow claimed that in 1958 Lebanon "merely broke down into... the shattered mosaic that it always becomes in bad times."79 In 1975, on the eve of Lebanon's second civil war, this assertion had not lost its relevance. A Christian invitation to help rid Lebanon of the threat of the PLO signified the first step towards a Syrian occupation. History had demonstrated that co-existence between Lebanon's communities was not impossible, but Syria's entrenchment in Lebanon's crisis meant that peace would be a long time coming and that the path towards it would be a Syrian one. However, Syria was not alone in its dominance; the USA had long viewed Syria as a key player in the Middle East peace process. At the outbreak of civil war, Henry Kissinger had talked of the Lebanese crisis as opening "a unique peace window" in the Middle East. ${ }^{80}$ But this "peace window," it seems, never did open.

\section{T'aif: Too Little Too Late?}

Elizabeth Picard describes the end of hostilities in 1990, as ceasing "as illogically as they had begun." 81 Illogical or not, this end could not have come sooner for Lebanon, whose people had endured fifteen years of devastating conflict.

Surveys conducted amongst Lebanon's economically active citizens in the 1980s emphasised the overwhelming desire amongst participants from all communities for peaceful coexistence, a form of consociational democracy, and unity. ${ }^{82}$ Most participants categorised themselves as economically dissatisfied, afraid of the

\footnotetext{
${ }^{79}$ Charles Winslow, op.cit., 113.

${ }^{80}$ Michael Kerr, “A Positive Aspect to the Tragedy of Lebanon: the Convergence of US, Syrian and Israeli Interests at the Outset of Lebanon's Civil War," Israeli Affairs, Vol. 15, No.4 (2009), 355-371.

${ }^{81}$ Elizabeth Picard, Lebanon: A Shattered Country (New York: Holmes and Meier, 1996), 115.

${ }^{82}$ Theodor Hanf, op.cit., 534.
} 
future, and powerless. ${ }^{83}$ Unsurprisingly perhaps, those who were not "economically dissatisfied" or "powerless" - the ruling elites-resisted such unity. The survey findings suggest the existence of, or a potential for, a unified Lebanese identity. Yet, encouraging as it may be, this does not equate to national identity, nor the existence of a "nation" per se.

The crucial point is that the political arrangements laid out by the Ta'if Agreement in 1989, which brought about an end of conflict in Lebanon, failed to reflect the desires expressed through these surveys. In theory, Ta'if aimed to reduce sectarianism through the restructuring of Lebanon's political system, as defined by the National Pact. It afforded greater power to Lebanon's Muslim communities, and restricted the political clout of the Maronites who had enjoyed a privileged position under French rule. Under the new Ta'if regime Lebanon's Christians maintained a position that was deemed disproportionate to their demographic strength; they managed to hold on to the post of President of the Republic, albeit one with reduced powers. Conversely, the Sunnis kept their allotted post of Prime Minister (with enhanced powers,) while the Shias, now arguably Lebanon's largest community numerically speaking, retained an empowered Speakership of the Chamber of Representatives. Of most significance, the Ta'if Agreement paved the way for the transfer of power from the Maronite President to the Council of Ministers, with the Prime Ministership firmly in Sunni hands, reducing the role of the President, and marking an overall shift away from presidential government, towards cabinet collegiality. ${ }^{84}$ In reality, the Agreement amounted to the re-instatement of the pre-existing power-sharing arrangement and in many ways represented a continuation of the National Pact, though this time under Syrian control. ${ }^{85}$ These realities, along with the placement of Lebanon solidly under Syrian tutelage, were far removed from the aspirations of Lebanese society as a whole. In fact, the first draft for negotiation at Ta'if was rejected in favour of a version resulting from consultations among Lebanon's elites. ${ }^{86}$ Allegations of bribery followed, as did a realisation that peace was unachievable without Syrian involvement. The Ta'if Agreement was ratified on 5th November 1989, and thus Lebanon's elite system of yore was consolidated. ${ }^{87}$

While the predominantly Sunni quest for Arab unity had been central to the National Pact, differing interpretations of the Pact along broadly Christian and Muslim lines meant that championing Arab nationalism as a defining feature was

\footnotetext{
${ }^{83}$ Ibid., 480.

${ }^{84}$ Michael Kerr, op.cit, 161.

${ }^{85}$ Ibid, 160.

${ }^{86}$ Ibid., 155.

${ }^{87}$ John Rolland, op.cit., 48.
} 


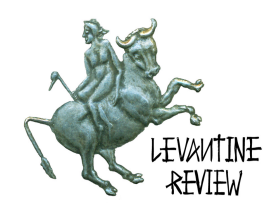

approached with caution. In contrast, the Ta'if Agreement attributed a distinctly Arab profile to Lebanon, which facilitated and legitimised Syria's rise and domination of the country. ${ }^{88}$ Furthermore, catalysed by a mutual dislike for the Syrians, Palestinians, and Israelis, all communities within Lebanon now viewed themselves as "Lebanese." ${ }^{9}$ For Hanf, this convergence was reflected in the Ta'if Agreement which was "rooted in common suffering, a common yearning for peace and a common desire for independence from everybody." 90 These points may indicate progress, but arguably such "roots" had existed long before Ta'if. Moreover, the "roots" planted through the Ta'if Agreement were not Lebanese creations.

However, with Lebanese society uniting in opposition to Syrian dominance, perhaps Hanf is correct in his view that the civil war might have led to the rise of a Lebanese nation. But, just as opposition to French rule was not enough to unite Lebanon for any length of time in 1943, so was there little to suggest that some united opposition to Syrian rule would fare better. Significantly, however, following the end of the civil war, most Lebanese agreed that, despite its defects and blemishes, their state was still well worth saving. ${ }^{91}$ Furthermore a commitment to coexistence within the state persisted.

Hanf explains that the intensification of war led to a decreased desire for consociation and coexistence, but that desire returned when the fighting ceased. ${ }^{92}$ This is contrasted with his claim that a sense of nation appeared only when Lebanon's existence was in mortal danger. ${ }^{93}$ Therefore, while the desire for coexistence has always resumed, a sense of nation is perhaps more transient, disappearing as rapidly as it emerges. Maybe there is more to be said for quiet coexistence than fervent nationalism.

\section{An Unfinished Revolution}

From 1990 to 2005 Lebanon experienced a period of relative calm, but the assassination of former Prime Minister Rafiq al-Hariri, on 14th February 2005 launched Lebanon once again into political turmoil. During his time as Prime Minister, Hariri's "larger than life" presence dominated the country, as did his grand plans for Lebanon's reconstruction and development. ${ }^{94}$ But Hariri's plans were

\footnotetext{
${ }^{88}$ Michael Kerr, op.cit., 167.

${ }^{89}$ Ibid., 17.

${ }^{90}$ Theodor Hanf, op.cit., 641.

${ }^{91}$ Kamal Salibi, A House of Many Mansions: The History of Lebanon Reconsidered, op.cit., 193.

${ }^{92}$ Theodor Hanf, op.cit., 546 and 550.

${ }^{93}$ Ibid., 642.

${ }^{94}$ Nicholas Blanford, Killing Mr Lebanon: The Assassination of Rafik Hariri and its Impact on the Middle East (London \& New York: I.B Tauris \& Co.Ltd, 2007), viii.
} 
obstructed by political realities; notably, his struggles with President Emile Lahoud and Syria's Bashar al-Assad. Although Hariri stepped down as Prime Minister in October 2004, Syria still viewed him as a threat. ${ }^{95}$

Rather than dividing Lebanon, however, Hariri's assassination achieved the opposite; sparking the "peaceful and democratic intifada for independence," also known as the "Cedar Revolution." 96 This mass mobilisation of Lebanese society against the state and against Syrian control presented opportunity for growth. Yet it not only failed to yield any real results, but was followed by further conflict and a reversion to sectarian allegiances.

Furthermore, while demonstrators claimed victory on the resignation of the Syriancontrolled Government in February 2005, and the announcement of Syrian troop withdrawal shortly thereafter, ${ }^{97}$ not all parties inside Lebanon were jubilant. To wit, Hizballah and Amal opposed Syria's withdrawal and the Uinted Nations' call for disarmament; additionally, Hassan Nasrallah urged political leaders to strengthen Lebanese-Syrian relations and protect Hizballah's military resistance against Israel. ${ }^{98}$ Demonstrations led predominantly by Lebanese Shia, including Hizballah and Amal, as well as the Christian-dominated Orange Movement followed on $8^{\text {th }}$ March. This was a disappointment for the opposition movement composed of civil society organisations and myriad political parties such as the Phalangist/Kata'ib, the predominantly Sunni Future Movement, the Druze-led Progressive Socialist Party, and the multi-confessional Democratic Left. But ambiguities in Shia loyalties were evident; whilst protesting the departure of Syrian troops, demonstrators brandished the cedar flag, displaying their allegiance to the state, ${ }^{99}$ again pointing to the complexities and layers constituting identity. Moreover, mindful of their disadvantaged socio-economic and political standing, for many Lebanese Shia, protecting their interests came before national identity.

\footnotetext{
${ }^{95}$ William Harris, "Bashar al-Assad's Lebanon Gamble”, The Middle East Quarterly, Vol.12, No.3, (Summer 2005), 33-44.

${ }^{96}$ Maria.J Stephan \& Rudy Jaafar, “Lebanon's Independence Intifada: Dynamics, Achievements, and Shortcomings", The American Political Science Association (APSA) (Philadelphia, PA; August 31September 3, 2006), 13, and Barry Rubin, (edt) Lebanon: Liberation, Conflict and Crisis (New York: Palgrave MacMillan, 2009), 4.

97 'Syrian Troops Leave Lebanese Soil', BBC News, Tuesday $26^{\text {th }}$ April 2005, http://news.bbc.co.uk/1/hi/4484325.stm

${ }^{98}$ Karim Knio, "Is Political Stability Sustainable in post-Cedar Revolution Lebanon?", Mediterranean Politics, Vol.13, No.3, (2008), 445-451, 447.

${ }^{99}$ Oussama Safa, "Getting to Arab Democracy: Lebanon Springs Forward”, Journal of Democracy, Vol.17, No.1, (2006), 22-37, 33.
} 


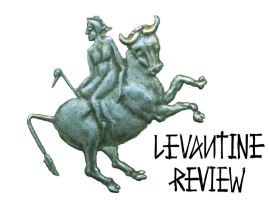

In response to what became known as the $8^{\text {th }}$ March Movement, and to commemorate Hariri's death, Lebanon's plural opposition planned a mass gathering for $14^{\text {th }}$ March, this time with the media and international community in mind. The rally, attended by Lebanese from all communities, took place without a single rock thrown, or glass broken. ${ }^{100}$ Overwhelming pressure, and failure to form a government, led to then Prime Minister Karami's second resignation. ${ }^{101}$ The ensuing elections yielded good results for the $14^{\text {th }}$ March Movement, and prepared the way for Hizballah's participation in government. However, two camps had now emerged.

From June 2005 to February 2006, attempts to push through proposals aimed at recovering Lebanese sovereignty were consistently blocked by Hizballah, leading to political paralysis and further polarisation, expressed along increasingly sectarian and pro or anti-Syrian lines. ${ }^{102}$ Ultimately, Lebanon's confessional system remained in place and opportunities for change were again lost. The fear of altering a comfortable status quo caused Lebanon's leaders to resume stances defined by sect and status. As Sensenig-Dabbous observes, "[t]raditionally, elections have merely demonstrated how successful the corrupt Lebanese elites and neighbouring powers have been at robbing the country of its future." 103 The elections of 2005 did little to refute this.

In reality, the Cedar Revolution fell short of a revolution at all, and in the eyes of some, amounted to little more than a Sunni, Druze and Maronite attempt to create an alternate National Pact. ${ }^{104}$ A main weakness in the Cedar Revolution's design was that its leaders did not plan beyond Syrian withdrawal. This resulted in the disintegration of the movement before long-term reforms could be achieved. ${ }^{105}$ Moreover, with Emile Lahoud, a Syrian ally, still in power, Lebanon was not free from external influence or internal divisions, thus preventing any real progress.

But the fact remains that the Cedar Revolution-fundamentally a home-grown movement ${ }^{106}$ - contributed, through non-violent means, to the downfall of a regime and the end of an occupation. For the first time since the Civil War, Lebanon was making headlines worldwide, compelling the international community to react. ${ }^{107}$

\footnotetext{
${ }^{100}$ Maria J. Stephan \& Rudy Jaafar, op.cit., 24.

${ }^{101}$ Karim Knio, op.cit., 448.

${ }^{102}$ Ibid., 447.

${ }^{103}$ Eugene Sensenig-Dabbous, "Lebanon: Point of No Return”, Mideast Web, 3 rd June 2005, www.mideastweb.org/log/archives/00000340.htm

${ }^{104}$ Ersun Kurtulus, "The Cedar Revolution: Lebanese Independence and the Question of Collective SelfDetermination”, The British Journal of Middle Eastern Studies, Vol.36, No.2., (2009), 195-214, 196

${ }^{105}$ Ibid., 1 .

${ }^{106}$ Maria J. Stephan \& Rudy Jaafar, op.cit., 26.

${ }^{107}$ Oussama Safa, op.cit., 33.
} 
By using the Lebanese flag as the symbol of the Cedar Revolution, activist Eli Khoury explained that the Lebanese aimed to "...show the world... that those from the different religions, at the end of the day, truly and honestly were Lebanese before anything else." 108 Yet just one year following Khoury's euphoric claims, Bank Byblos reminded us that this was not necessarily the case.

Moreover, determining what Khoury meant by 'Lebanese' remained an ambiguous concept. We are reminded however, that identity - national or otherwise-can never be fully articulated. Lebanon's Shia, Sunni, Maronite, and Druze communities, and denominations within them, undoubtedly have different interpretations of what being Lebanese means; interpretations being shaped by their individual experiences, environments and histories. Yet those might all be deemed Lebanese experiences, each equally valid. Indeed, national identity does not necessitate uniformity, though admittedly, its divergent versions should gravitate at some level towards shared or at least compatible visions.

But the Cedar Revolution did indicate such visions, and in many ways had the makings of a positive turning point in Lebanon's history. With an improving economic situation and the absence of war, co-existence between Lebanon's confessional groups, where it had existed, dis resume. The assassination of Hariri did not undo these positive developments. Rather, Lebanese society rallied in defiance of Syrian control (and official Lebanese collaboration,) and called for fundamental changes. It appeared that with public support and with Lebanon's political leaders setting their differences aside-albeit ever fleetingly-Lebanon both as a nation and a political entity would be neither willing nor able to go back. But, in the final analysis, the outcomes of the Cedar Revolution represented a continuity of the old political system in the confessional nature of the Lebanese politics; the existence of trans-national alliances, and recurrent external interventions in internal politics. ${ }^{109}$

The years that followed validated the doubts surrounding the Cedar Revolution. 2006 was marred by Hizballah-Israeli clashes, and 2008 witnessed widespread armed conflict, this time between Hizballah and the state. Fighting was eventually halted through the Lebanese National Dialogue Conference in Doha and the formation of a "national unity government" under Michel Sulieman. But any optimism was not accompanied by a new era of political reconciliation. ${ }^{110}$ Like Ta'if,

${ }^{108}$ Interview with Eli Khoury in ibid., 17.

${ }^{109}$ Ersun Kurtulus, op.cit., 214.

${ }^{110}$ Karim Knio, op.cit., 446. 


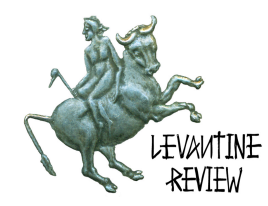

the outcomes of Doha amounted to a ceasefire rather than permanent closure of Lebanon's troubles. However, as one Lebanese woman asserted in the aftermath of the Cedar Revolution "It will take fifteen years if we all start working now... But fifteen years is OK. We've wasted the last thirty doing nothing."111

\section{Conclusions}

At this point we are compelled to consider how a "point of no return" can be measured. The field of conflict resolution contributes to the understanding of factors involved in ending violent conflict and strengthening a state in the hope of inhibiting regression. Where violent conflict is present, the role of the state in reaching a "point of no return" is crucial: "At whatever level the main source of contemporary conflict may be seen to reside it is at the level of the state that the critical struggle is in the end played out."112 Lebanese-born Edward Azar, an expert in "protracted social conflict," believes that for conflicts to be permanently resolved, state institutions must be decentralised in order to meet the needs of both individuals and groups within a nation-state, in psychological, economic and relational terms. ${ }^{113}$ In Lebanon, extensive political decentralisation is not matched by a relinquishment of control by the powerful individuals that form the bedrock of Lebanon's tradition of patronage. Permanent resolution of conflicts depends upon the willingness of actors to limit personal power for the good of the community they serve. There is little evidence of this in Lebanon to date.

Assessing whether Lebanon has reached a point of no return in terms of identity and nationalism is not straightforward, and Lebanon has encountered many crises and crossroads throughout its turbulent recent history. Theodor Hanf claims that out of these "nodal points," in particular the Lebanese civil war of 1975, emerged a Lebanese nation where one had not existed prior. However, this analysis considers the possibility that a form of "nation" had in fact existed for many years, relegating struggles over Lebanon and the nationalism debate to the realm of the political elite and external actors. At several points in Lebanon's history, common identity referents and shared goals were evident, but not encouraged. Maybe then, Lebanon's nodal points have not taken identity and nationalism beyond a "point of no return," but have, at various times, served to both suffocate existing identities and facilitate their expression.

\footnotetext{
${ }^{111}$ Rory McCarthy, "Lebanon's Cedar Revolution Withers", The Guardian, Saturday $22^{\text {nd }}$ October 2005

${ }^{112}$ Hugh Miall, Oliver Ramsbotham \& Tom Woodhouse, Contemporary Conflict Resolution: The Prevention, Management and Transformation of Deadly Conflicts (Cambridge UK \& Malden USA: Polity Press, 2005), 107.

${ }^{113}$ Edward Azar \& John Burton, International Conflict Resolution: Theory and Practice (Sussex: Wheatsheaf, 1983), 33-34.
} 


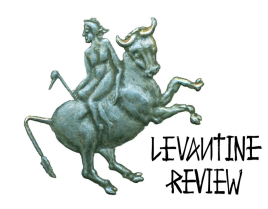

Lebanon's contradictions have both aided Lebanon and led to its destruction. Lebanon's openness and diversity have fostered tolerance and the ability to co-exist, but these same characteristics have left the country vulnerable to abuse. Syria has long wielded control over Lebanon to the detriment of Lebanese sovereignty, yet arguably without Syria, war would not have ended in 1990. Elite intransigence, external control and the persistence of a flawed political system have impeded Lebanon's development both politically and socially. But it is precisely these grievances that have compelled Lebanese society to unite in displays of mass solidarity.

However, these contradictions represent not a weakness of Lebanese identity, but weakness inherent in the imposition of identities. The fragility of "imposed identities" is exposed by their short life-span and the ease with which traditional allegiances have resumed. This is not surprising. The trust required to build secure identities has rarely been provided by the state. Instead, it has consistently derived from the family, the tribe, the sect. These ties do not necessarily come at the expense of "nation"; instead, the complex nature of identity allows for allegiances along multiple lines.

On Mount Lebanon, there was a realisation of the need for compromise and recognition of the benefits of coexistence for the purpose of survival. This early model of cooperation is echoed by collaboration through the years between Christians and Muslims, Lebanese and Arab nationalists, and society in general in the absence of war. In some respects, modern Lebanon, therefore, is not so far removed from the Lebanon of the 1800s. Despite the absence of allegiance to the state, in 1860 just as in 1958 and 1989, the thrust was to continue with a commitment to Lebanon, indicating consensus that the country, in its varying forms, was well worth saving.

Ironically, however, as Lebanon achieved greater independence, external influence appeared to increase, and with it, attempts to shape Lebanon's identity and experiences of nationalism. The dwindling options available to Lebanon through its crises may have pushed the country towards a "point of no return," but this was not a Lebanese achievement; rather, it signifies a reduction in autonomy and a rise in external control. Each nodal point has yielded similar outcomes whilst failing to significantly affect identities and nationalism in Lebanon, thus, going some way to confirm suspicions that the Lebanese have long known who they are, if only they were allowed the space to express it.

While Lebanese society has demonstrated unity, it is the political system, dominated by self-interested elites and foreign powers, that has prevented real progress. The 


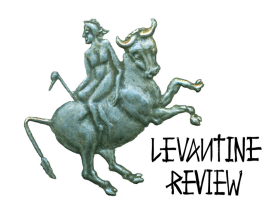

"point of no return" may only be found when the dominance of Lebanon's traditional elites along with that of their external sponsors is dismantled. This is a task not only for Lebanon, but for the regional and international powers who see benefit in maintaining the status quo or in fighting their own battles in somebody else's back yard. ${ }^{114}$

Continuing this "tradition" of external impact, troubles loom on the edge of Lebanon's peace with the so-called "Arab Spring" sweeping the region. However, Lebanon's experience will not mirror those gripping other states across the Middle East. Unlike its Arab neighbours, Lebanon has never been an autocracy, and despite internal scission, Lebanon's denominational democracy remains a democracy nonetheless, albeit a flawed and saddled one. As a result, while unrest in Syria undoubtedly poses a threat to stability in Lebanon, a Lebanese "Arab Spring" would not be characterised by a popular uprising against the state, but rather by a fight against corruption, mingled with Israeli-American interests positioned against Iran and its allies. Perhaps there is cause for optimism here. While external pressures and inextricable ties to Syria could shape Lebanon's experience once more, an uprising in Lebanon would, to some degree at least, be a uniquely Lebanese affair.

Returning to the question posed at the outset-“When will we all be Lebanese?"such inquiries are nothing new. Thomas Friedman, writing after the civil war of 1975-1990 commented that

The Lebanese individual traditionally derived his social identity and psychological support from his primordial affiliations-family, neighbourhood, or religious community, but rarely from the nation as a whole. He was always a Druze, a Maronite or a Sunni before he was a Lebanese; and he was always a member of the Arslan or Jumblatt Druze clans before he was a Druze, or a member of the Gemayel or Franjieh Maronite clans before he was a Maronite. ${ }^{115}$

Whilst these "micro societies" helped Lebanon to survive hardships when national government disappeared, they also inhibited the emergence and survival of a strong national government and national identity.

History attests to the fact that the question over Lebanese identity and nationalism is far from resolved. Lebanon's diversity has been a double-edged sword; its downfall and its saviour. For a country and peoples that are in many respects

\footnotetext{
${ }^{114}$ Michael Kerr, op.cit.

${ }^{115}$ Thomas Friedman, From Beirut to Jerusalem (New York: First Anchor Books, Random House, 1995), 46.
} 
Stewart / The Levantine Review Volume 1 Number 2 (Fall 2012)

"Western" in their outlook, yet firmly anchored in their Arab milieu, the struggle to synthesise what it is to be essentially Lebanese continues.

*Hannah Stewart is a Middle East-based independent scholar working in the field of international development. She is Executive Editor for Forbes-Middle East, and holds a Master's degree in Middle East and Mediterranean Studies from King's College London, where she studied under the guidance of Professor Michael Kerr. 